\title{
Calosoma aethiops (Jeannel, 1940) as a new synonym of Calosoma imbricatum hottentotum Chaudoir, 1852, a new status of Calosoma roeschkei Breuning, 1927, and a revision of the Calosoma senegalense group sensu Häckel, 2012 (Coleoptera, Carabidae, Carabini)
}

\author{
Martin Häckel', Jan Farkač', Rostislav Sehnal ${ }^{2}$
}

I Department of Game Management and Wildlife Biology, Faculty of Forestry and Wood Sciences, Czech University of Life Sciences, Kamýcká 1176, CZ-165 21 Prague 6-Suchdol, Czech Republic 2 V Zahrádkách 962, CZ-273 51 Unhošt', Czech Republic

Corresponding author: Martin Häckel (hackel@uvn.cz)

Academic editor: A. Casale | Received 11 October 2015 | Accepted 25 April 2016 | Published 8 August 2016

http://zoobank.org/91E491A4-07C5-448C-BA83-1E4FAB807066

Citation: Häckel M, Farkač J, Sehnal R (2016) Calosoma aethiops (Jeannel, 1940) as a new synonym of Calosoma imbricatum hottentotum Chaudoir, 1852, a new status of Calosoma roeschkei Breuning, 1927, and a revision of the Calosoma senegalense group sensu Häckel, 2012 (Coleoptera, Carabidae, Carabini). ZooKeys 609: 11-28. doi: 10.3897/ zookeys.609.6822

\begin{abstract}
Calosoma aethiops (Jeannel, 1940) as a new synonym of Calosoma imbricatum hottentotum Chaudoir, 1852, a new status of Calosoma roeschkei Breuning, 1927, and a revision of the Calosoma senegalense group sensu Häckel, 2012 (Coleoptera: Carabidae: Carabini). Conducted is a taxonomic revision of the Calosoma senegalense group sensu Häckel, 2012. Placed in the group sensu stricto are four species: C. planicolle Chaudoir, 1869, C. scabrosum Chaudoir, 1843, C. senegalense Dejean, 1831, and C. strandi Breuning, 1934. Calosoma aethiops Jeannel, 1940 is synonymized with C. imbricatum hottentotum Chaudoir, 1852, and C. roeschkei Breuning, 1927 is newly regarded as a subspecies of $C$. scabrosum. The taxonomic conclusions are based on morphometry of the holotypes and 10 male and 10 female specimens of each taxon, and on morphology of the aedeagus including inflated endophalus.
\end{abstract}

\section{Keywords}

Carabidae, Carabinae, Calosoma, new synonymy, Africa

Copyright Martin Häckel et al. This is an open access article distributed under the terms of the Creative Commons Attribution License (CC BY 4.0), which permits unrestricted use, distribution, and reproduction in any medium, provided the original author and source are credited. 


\section{Introduction}

Calosoma is the second most speciose genus of the subfamily Carabinae, with 168 (Lorenz 2005), 128 (Bruschi 2013) or 129 (Häckel 2013) species described from all zoogeographic regions. Most species are excellent fliers widely distributed on all continents and numerous islands, but some are secondarily brachypterous or apterous with narrow distributions (Bruschi 2013, Häckel 2012). Some species inhabit more zoogeographic regions, and some extend to a neighboring continent that belongs in the same zoogeographic region (Häckel 2012). Examples of such distributions are some species of the $C$. maderae group (C. imbricatum subgroup sensu Häckel 2013) and of the $C$. senegalense group ( $C$. senegalense subgroup sensu Häckel 2013), which inhabit the area of the Horn of Africa. The distributions are probably to some extent responsible for the unsettled situation in the species-level taxonomy of the group (Bruschi 2013, Häckel 2012, 2013, Häckel \& Farkač 2012), a part of which this paper attempts to resolve. At the same time it respects the recent supraspecific classification (Häckel 2013), which in light of the known genetic analyses (Su et al. 2005) does not support the traditional subgeneric divisions.

\section{Material and methods}

The classification of the group is based primarily on external structural details of the adult, with species-level taxonomy relying also on structural details of the expanded endophalus. The aedeagi were dissected, preserved, studied dry and glued on cards appended beneath the dissected specimens. For study of the endophalus, the aedeagus was soaked 48 hours in 1:1 solution of water and $8 \%$ acetic acid, and then the endophalus was inflated using a small Heavy Duty $(12 \mathrm{~V})$ compressor normally used to inflate tires, set at medium pressure. Fixation of the endophalus morphology was secured by slow drying on a portable electric $(220 \mathrm{~V})$ single-plate heater, and the whole aedeagus-endophalus preparation was then glued on a paper card. The preparations were photographed by Canon G10 Digital Compact in macrophoto regime with flash. Aedeagi were photographed in the right lateral view, with details of their tips also slanted at an angle.

Inspected and evaluated were the following morphometric parameters of the holotypes and 20 samples (10 males and 10 females) of each species:

a) total length of the adult including mandibles (TL),

b) maximum head width including eyes to maximum pronotal width ratio (WP/WH),

c) maximum pronotal length to maximum width ratio (WP/LP),

d) maximum elytral length to maximum width ratio (LE/WE).

Subjective evaluations included also differences in termination of the aedeagus (apex) and of the inflated endophalus. Measured were morphometric parameters of 10 males and 10 females of the following taxa: C. planicolle, C. scabrosum scabrosum, $C$. scabrosum roeschkei, C. senegalense, C. strandi (all taxa belong to C. senegalense group), 
and C. imbricatum imbricatum from populations inhabiting the Afrotropical region (including Oman and Yemen on the Arab peninsula) and C. imbricatum hottentotum (C. maderae group, C. imbricatum subgroup). Measured holotypes include C. scabrosum (Chaudoir), C. scabrosum roeschkei (Breuning), C. imbricatum hottentotum (Chaudoir) and C. aethiops (Jeannel).

The material examined is housed in the collections listed below:

cMNHN Muséum national d'Histoire naturelle, Paris, France

cNBCL National Biodiversity Center, Leiden, Netherlands

cNMP Národní muzeum, Prague, Czech Republic

cFAR Jan Farkač collection, Prague, Czech Republic

cHAC Martin Häckel collection, Hostivice, Czech Republic

cSEH Rostislav Sehnal collection, Unhošt, Czech Republic

cWRA David W. Wrase collection, Berlin, Germany

\section{Systematic part}

\section{C. senegalense species group (sensu Häckel 2013): \\ C. senegalense subgroup (= C. senegalense group s. str.)}

\section{Calosoma (Calosoma) planicolle Chaudoir, 1869}

Plate 4: Fig. 4

Calosoma planicolle Chaudoir, 1869: 369 (type loc. "près du Zambéze", type in cMNHN). Calosoma procerum Harold, 1880: 260 (type loc. "Taita District, Kenya Colony, Ukamba”), syn. sn. Breuning 1927: 188.

C. (Ctenosta) planicolle Breuning, 1927: 188. Lapouge 1932: 415; Deuve 1978: 250; Culot 1990: 9; Lorenz 2005: 68; Bruschi 2013: 132.

Ctenosta (s. str.) planicolle Jeannel, 1940: 130. Rougemont 1976: 248; Vigna Taglianti and Bruschi 1986: 22.

Calosoma (s. str.) planicolle Häckel, 2013: 30.

Material studied. BOTSWANA. $1{ }^{\Uparrow}, 3 q$ : Ngamiland district, ne. of Maun, Tamalakane (cHAC).

KENYA. $1 \hat{\jmath}, 1 q$ : Tsavo, Mtitoanday (cSEH); $1 \hat{\jmath}, 1 q$ : Eastern 729, Sosoma, 202 $\mathrm{km}$ E of Thika (cSEH).

MOZAMBIQUE. 1\%: Sofala province, $30 \mathrm{~km} \mathrm{~S}$ Caia (cSEH).

Namibia. $1 \delta^{\lambda}$ : Kavango reg., Okavango river, Rundu, 1050 m (cHAC); 10, 1 우 Caprivi reg., Bagani- Popa Falls (cHAC).

Zambia. $1 \delta^{\text {: }}$ Southern Prov., Livingstone env., Victoria Falls (cHAC). 
Zimbabwe. 1§̄, 2q: Midlands Prov., Kwekwe env. 20 km w. Ngezi Park (cHAC);

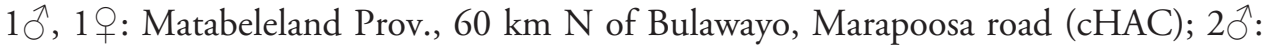
Masvingo province, $95 \mathrm{~km}$ NE Beitbridge, Bubi river (cSEH)

Distribution. Angola, Botswana, Democratic Congo, Ethiopia, Kenya, Lesotho, Madagascar, Malawi, Mozambique, Republic of South Africa, Somalia, Tanzania, Swaziland, Uganda, Zambia, Zimbabwe.

\section{Calosoma (Calosoma) scabrosum scabrosum Chaudoir, 1869}

Plate 1: Fig. 1. Plate 2: Figs 1-2. Plate 4. Fig. 1.

Calosoma scabrosum Chaudoir, 1843: 745 (type loc. "Kordofan").

Calosoma kordofanum [Kollar in litt.] syn. sn. Chaudoir 1852: 100.

Calosoma (Ctenosta) scabrosum Breuning, 1927: 185. Lapouge 1932: 414; Deuve 1978:

250; Culot 1990: 9; Lorenz 2005: 68; Bruschi 2013: 127.

Ctenosta (s. str.) scabrosum Jeannel, 1940: 128. Rougemont 1976: 247; Vigna Taglianti and Bruschi 1986: 21.

Calosoma (Ctenosta) jakli Häckel, Farkač \& Sehnal, 2005: 2 (type loc. "Oman: Dhofar”), syn. sn. Häckel et al., 2010: 11.

Calosoma (s. str.) scabrosum Häckel, 2012: 57. Häckel 2013: 31.

Type material. Calosoma scabrosum Chaudoir, 1869. 1ð labelled "HOLOTYPE / Ex Musaeo Chaudoir / Ctenosta scabrosum (Chd.) P. Basilewsky vid. 1992 (cMNHN); $1 ð$ labelled "SW Asia, S Oman, Dzhopar Prov., Al Mughsayi vill. env., 0-50 m a.s.l., VIII.1999, lgt. S. Jákl / HOLOTYPE Calosoma jakli det. Häckel, Farkač \& Sehnal, 2005 / Calsoma scabrosum det. Häckel, Farkač \& Sehnal, 2010” (cHAC).

Other material studied. Djibouti. 10 : "Obock" (cNMP).

Oman. 5q: Dzhophar Prov., Takwa env., 50 m a.s.l. (cFAR, cHAC, cSEH); 1 \%: rd. Al Mughsayi - Salalah, ca $3 \mathrm{~km}$ from Mughsayi, $20 \mathrm{~m}$ a.s.l. (cFAR); 1 \% : Dhophar Province, Takwa env., $200 \mathrm{~m}$ a.s.l. (cKAL); 3ð̄, 2ᄋ: Dzhofar prov., Wadi Nashib, $24 \mathrm{~km}$ E Salalah (cHAC, cSEH); 53 : Dzhofar prov., Wadi Nashib, $20 \mathrm{~km}$ E Salalah (cHAC, cSEH).

SENEGAL (Niger or Chad probably). 1q: "Senegal" (cNMP).

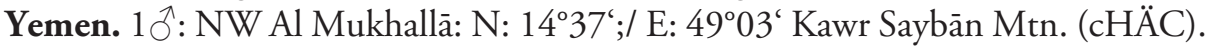

Distribution. Chad, Djibouti, Eritrea, Ethiopia, Kenya, Niger, Nigeria, Oman, Somalia, South Sudan, Tanzania, Yemen. Data from Burundi, Rwanda and Uganda need confirmation.

\section{Calosoma (Calosoma) scabrosum roeschkei Breuning, 1927}

Plate 1: Fig. 2. Plate 2: Fig. 3. Plate 3: Fig. 3. Plate 4: Fig. 2.

Calosoma (Ctenosta) scabrosum roeschkei Breuning, 1927: 185 (type loc. "Usambara”). Ctenosta (s. str.) aethiops (partim) Jeannel, 1940: 128 (loc. "Diré-Daoua”); Rougemont 1976: 247. Vigna Taglianti and Bruschi 1986: 21. 
Ctenosta (s. str.) orientale (partim) Jeannel, 1940: 129 (loc. "Érythrée: Tessenei").

Ctenosta (s. str.) scabrosum var. roeschkei Jeannel, 1940: 128.

Calosoma (Ctenosta) aethiops Culot, 1990: 9. Lorenz 2005: 68.

Calosoma (s. str.) scabrosum Häckel, 2012: 57. Häckel 2013: 31.

Calosoma (Ctenosta) roeschkei Bruschi, 2013: 129.

Type material. Calosoma roeschkei Breuning, 1927. 10 labelled "Usambara"(cNBCL).

Other material studied. Kenya. 1 $\hat{\jmath}, 1$ : $\mathrm{E}$ of Garsen, W of Witu (cSEH); $2 \hat{\jmath}$,

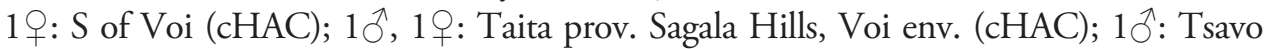
East, Voi Lodge, 3.23S/38.34E (cWRA); 19: NE prov. El Wak (cHAC); 1ð, 1 ; : Modo Gashi to Wajir (cHAC); $2 \widehat{\jmath}, 2$; : Coast province, Garissa, N of Bura (cHAC, cSEH), $1 \hat{\jmath}$ : Amboseli National Park (cSEH); 2 P: Eastern 729, Sosoma, 202 km E of Thika (cSEH).

Sudan. 10̂, 1O: Vad Medani (cSEH).

Geographic distribution. Chad, Kenya, Somalia, Sudan, Tanzania.

\section{Calosoma (Calosoma) senegalense Dejean, 1831}

Plate 4: Fig. 5

Calosoma sengalense Dejean, 1831: 562 (type loc. "Sénegal").

Calosoma mossambicense Klug, 1853: 247 (type loc. "Téte"). C. (Ctenosta) senegalense mossambicense Breuning, 1927: 187.

Ctenosta senegalense Motschulsky, 1865: 306.

Calosoma (Ctenosta) senegalense Breuning, 1927: 187. Lapouge 1932: 415. Deuve 1978: 247; Culot 1990: 9; Lorenz 2005: 68; Bruschi 2013. 131.

Ctenosta (s. str.) senegalense Jeannel, 1940: 129. Rougemont 1976: 248; Vigna Taglianti and Bruschi 1986: 21.

Calosoma (s. str.) senegalense Häckel, 2012: 58, 64; 2013: 31.

Material studied. Botswana. $1 \bigcirc, 1 \%$ : Ngamiland district, ne. of Maun, Tamalakane (cHAC).

Ethiopia. 10, 1우 : Gambela region, Gambela env., $400 \mathrm{~m}$ (cHAC).

Ghana. 10, 1우 Northern Prov., West Gonja district, Damongo env. (cHAC).

Kenya. $1 \hat{O}, 1$ : : Coast Prov., Taita-Taveta Co., s. of Voi (cHAC).

Madagascar. 1 $\hat{O}$, 2ᄋ: Toliara prov., Ampanihy district, Ejeda env. (c FAR, cHAC); $1 \widehat{O}^{\lambda}, 1$ : : Mahajanga Prov., Ampatika env., Mahajamba river (cHAC).

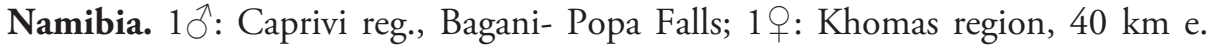
Windhoek (airport) (cHAC).

Senegal. 10 , 1 \% : Thiès region, M'bour department, Saly Portudal (cHAC).

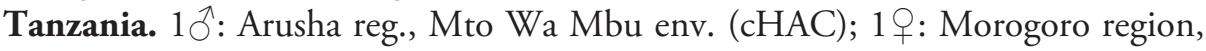
Mikumi (cHAC). Zimbabwe. $1 \delta^{\lambda}: 20 \mathrm{~km}$ NE Shamva, Nyagui river (cHAC).

Distribution. Angola, Benin, Botswana, Burkina Faso, Burundi, Cameroon, Cabo Verde Islands, Chad, Congo, Côte d'Ivoire, Democratic Congo, Eritrea, Ethiopia, Gabon, Gambia, Ghana, Guinea, Guinea-Bissau, Guinea Equatorial, Kenya, Lesotho, Li- 


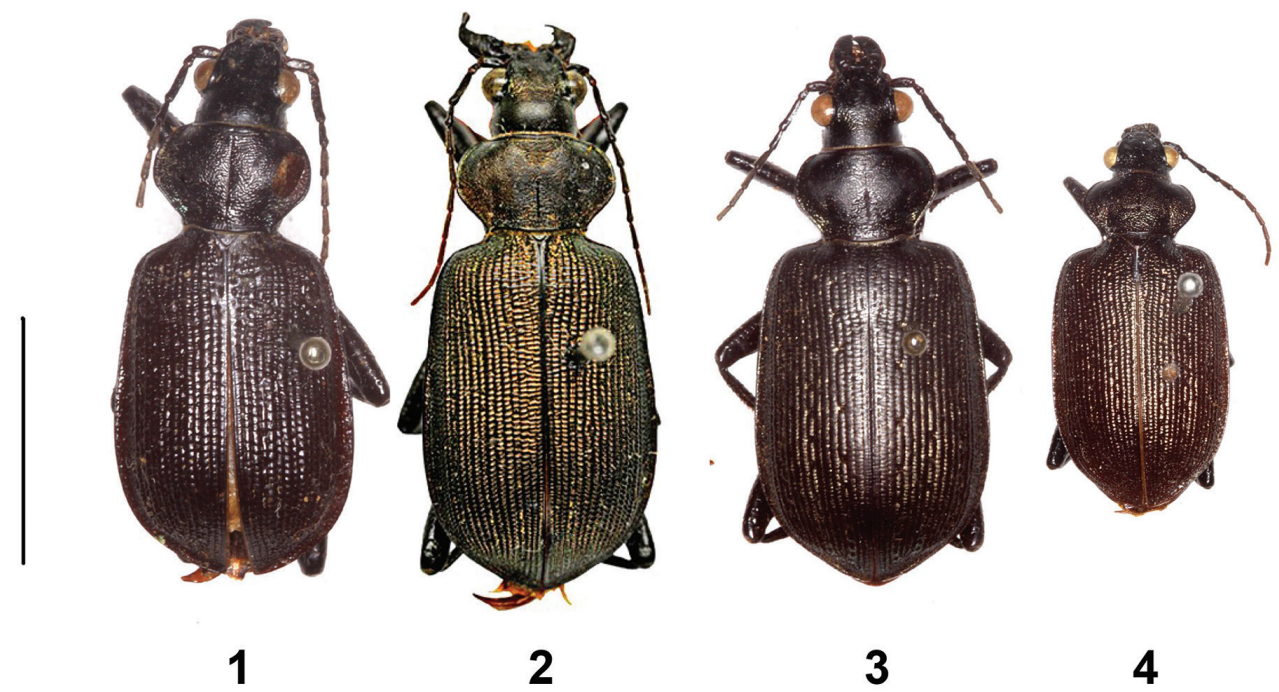

Plate I. Type material (habitus in dorsal aspect, male). Scale bar equals $10 \mathrm{~mm}$. I C. scabrosum scabrosum (holotype) 2 C. scabrosum roeschkei (holotype) 3 C. imbricatum hottentottum (holotype of Ctenosta aethiops Jeannel, 1940) 4 C. imbricatum hottentottum (holotype).

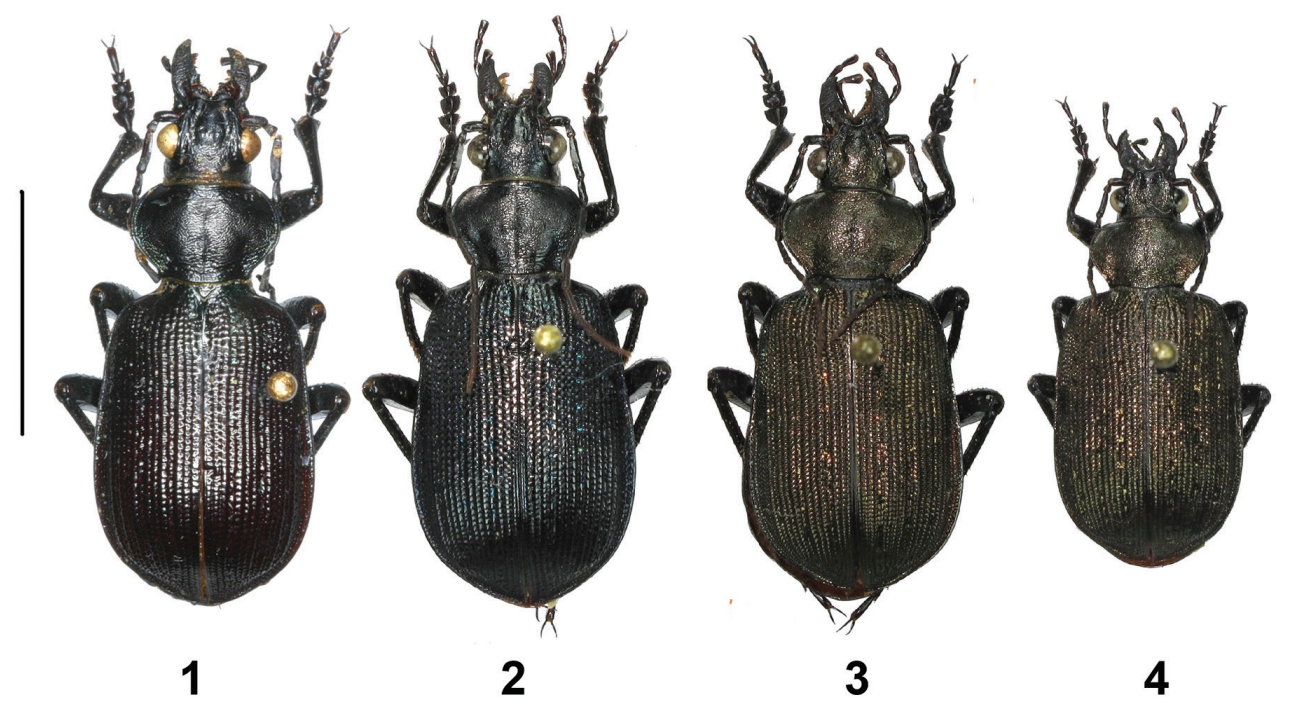

Plate 2. Material studied (habitus in dorsal aspect, male). I C. scabrosum scabrosum (Djibouti: Obock) 2 C. scabrosum scabrosum (Oman: Dhofar, holotype of C. jakli Häckel, Farkač \& Sehnal, 2005) 3 C. scabrosum roeschkei (Kenya: Voi env.) 4 C. imbricatum hottentottum (Namibia: Okahandja). Scale bar equals $10 \mathrm{~mm}$.

beria, Madagascar, Malawi, Mali, Mauritania, Mozambique, Namibia, Niger, Nigeria, Republic of Central Africa, Republic of South Africa, Rwanda, Senegal, Sierra Leone, Somalia, Swaziland, Tanzania, Togo, Uganda, Zambia, Zimbabwe. 


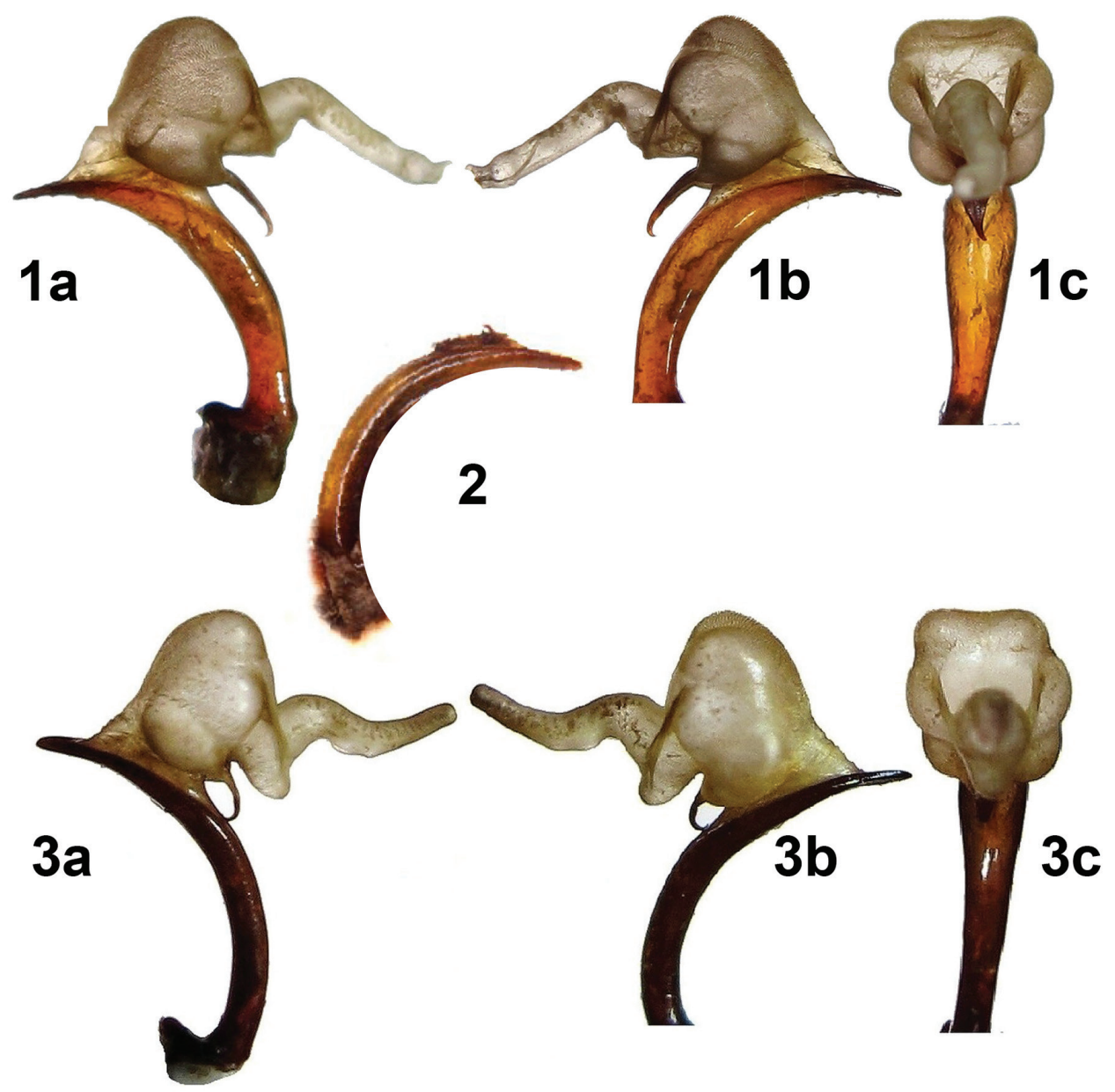

Plate 3. Aedeagi of C. imbricatum hottentotum (Namibia) and C. scabrosum roeschkei (Kenya) compared with aedeagus of "C. aethiops" (holotype). I C. imbricatum hottentottum (Namibia: Okahandja); a - aedeagus with expanded endophalus in right lateral view, b - the same in left lateral view, c - the same in anterior view 2 C. imbricatum hottentottum (holotype of Ctenosta aethiops Jeannel, 1940) aedeagus in left lateral view 3 C. scabrosum roeschkei (Kenya: Voi env.), a - aedeagus with expanded endophalus in right lateral view, b - the same in left lateral view, $\mathrm{c}-$ the same in anterior view.

\section{Calosoma (Calosoma) strandi Breuning, 1934}

Plate 4: Fig. 3.

Calosoma (Ctenosta) strandi Breuning, 1934: 38 (type loc. "Masaua"). Culot 1990: 9; Lorenz 2005: 68; Bruschi 2013: 130.

Ctenosta (s. str.) strandi Jeannel, 1940: 130. Rougemont 1976: 244; Vigna Taglianti and Bruschi 1986: 21.

Calosoma (s. str.) strandi Häckel, 2013: 31. 


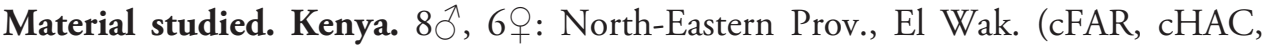
cSEH); $2 \hat{O}, 4$ : : Eastern Prov. Marsabit to South Horq (cFAR, cHAC, cSEH).

Distribution. Eritrea, Ethiopia, Kenya, Somalia.

\section{C. maderae species group (sensu Häckel 2013) \\ C. imbricatum subgroup}

\section{Calosoma (Calosoma) imbricatum imbricatum Klug, 1832}

Calosoma imbricatum Klug, 1832: pl. IX. (type loc. "Cap Vert"). Calosoma (Caminara) imbricatum Breuning, 1927: 221. Caminara (Caminara) imbricata Lapouge 1932: 410, Jeannel 1940: 104. Culot 1990: 7; Lorenz 2005: 69; Bruschi 2013: 76, Häckel 2013: 24.

Caminara arabica Motschulsky, 1865: 304. Caminara imbricata arabica Lapouge 1932: 410.

Calosoma (Caminara) loffleri Mandl, 1953: 57.

Calosoma (Caminara) loffleri m. rufoapendiculata Mandl, 1967: 44.

Calosoma (Caminara) linnavouri Mandl, 1970: 61.

Material studied. Kenya. $1 \hat{\delta}, 1 q$ : Marsabith to South Orr (cHAC).

Oman. 8ß̂, 8: Wadi Qitbit, 150m (cFAR, cHAC, cSEH).

Senegal. 1 : : Senegal (cHAC).

Sudan. $1{ }^{\widehat{T}}$ : Port Sudan (cHAC).

Distribution. Algeria, Cabo Verde Islands, Canarian Islands, Chad, Djibuti, Egypt, Eritrea, Ethiopia, western India, Iran, Iraq, northern Kenya, Kuwait, Libya, Mali, Niger, Oman, Pakistan, Saudi Arabia, Senegal, Somalia, Sudan, United Arab Emirates, Yemen.

Calosoma (Calosoma) imbricatum hottentotum Chaudoir, 1852

Plate 1: Figs 3-4. Plate 2: Fig. 4. Plate 3: Figs 1-2. Plate 4. Fig. 6.

Calosoma hottentotum Chaudoir, 1852: 99 (type loc. "Cap de bonne-Espérance"). Deuve 1978: 249.

Calosoma (Caminara) imbricatum hottentotum Breuning, 1927: 221. Mandl 1970: 61, 62; Culot 1990: 7; Lorenz 2005: 69; Bruschi 2013: 76.

Caminara (Caminara) imbricata hottentota Lapouge, 1932: 410. Jeannel 1940: 105. Ctenosta (s. str.) aethiops Jeannel, 1940: 127 (type loc. "Azbin, à 20 km. d'Agadès, dans l'Aïr"), new synonym.

Calosoma (s. str.) imbricatum hottentotum Häckel, 2013: 24.

Type material. 10 labelled "LECTOTYPE / Ex Musaeo Chaudoir / Calosoma hottentotum Lectotype Chaud. 1852 Th. Deuve det,. 1978” (cMNHN); 10 labelled 

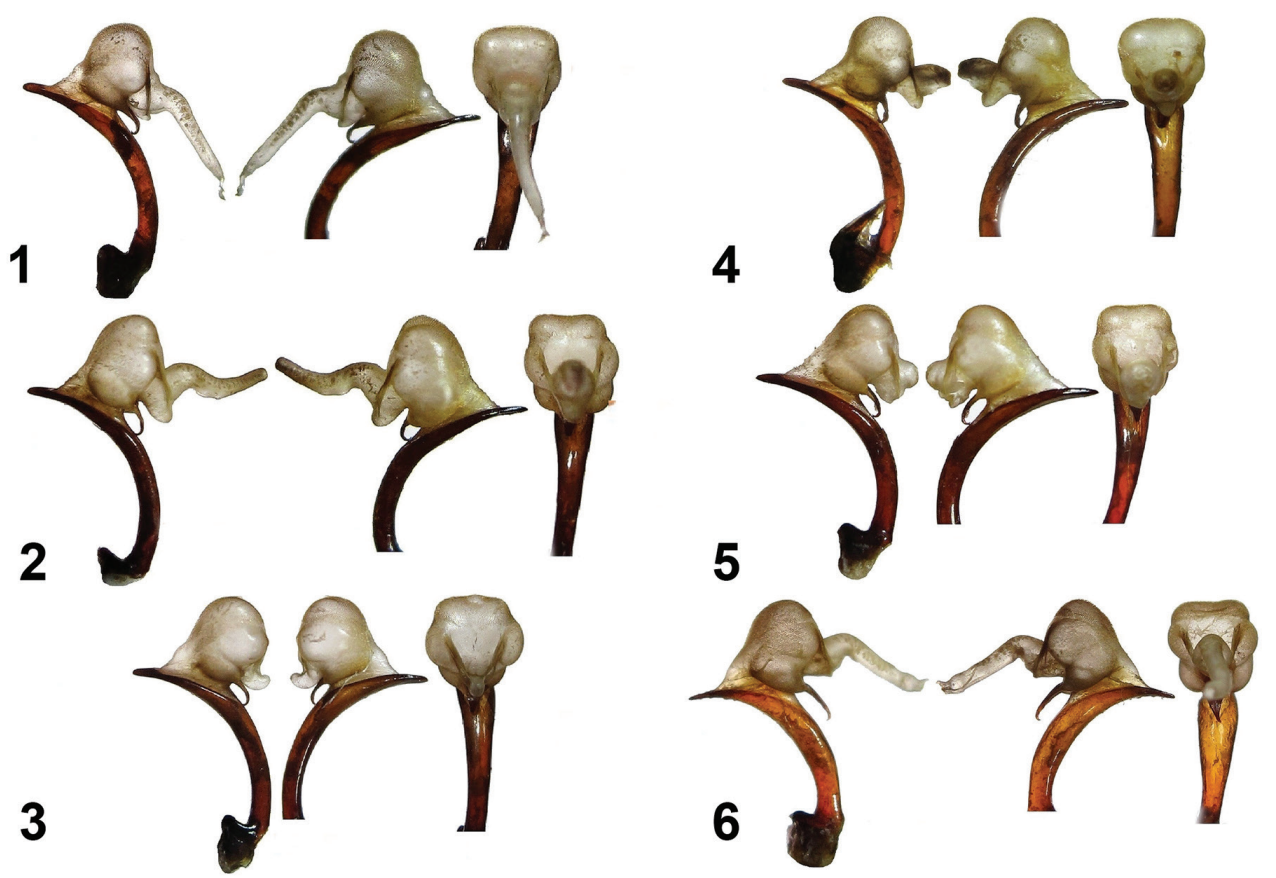

Plate 4. Aedeagi of C. senegalense species group (sensu Häckel 2012: 30) and C. imbricatum hottentotum (Namibia). a - aedeagus with expanded endophalus in right lateral view, b - same in left lateral view, csame in anterior view I C. scabrosum scabrosum (Oman: Dhofar) 2 C. scabrosum roeschkei (southeastern Kenya: Voi env.) 3 C. strandi (northeastern Kenya: El Wak) 4 C. planicolle (Namibia: Kavango) 5 C. senegalense (Zimbabwe: Shamva) 6 C. imbricatum hottentottum (Namibia: Okahandja).

"MUSEUM PARIS AZBIN (AIR) REG. de TINTABORAC $20 \mathrm{~K}$ E d' AGADÈS CAPde POSTH 1908 / HOLOTYPE / aethiops n. sp. Jeannel det." (cMNHN).

Other material studied. Kenya. 1§, 1q: Amboseli National Park (cSEH).

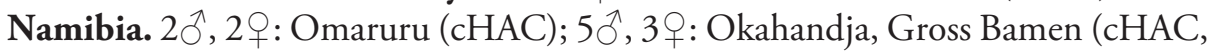

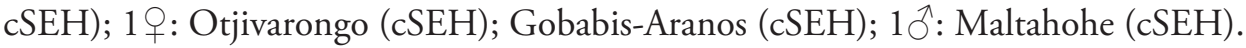

Republic of South Africa. 1 $\delta^{\lambda}, 3 q$ : Northern Cape Province, SW Kimberley, 13 km SW Ritchie (cHAC).

Distribution. Southern Kenya, Namibia, Tanzania, Republic of South Africa.

\section{Comments on classification}

Our study shows the following:

1. Termination (apex) of the aedeagus. We have found no difference in shape of the apex among species or subspecies within the same group, the shape is distinct only among species belonging to different groups. The apex of $C$. imbricatum (narrower 
and sharper, Plate 3: Figs 1-2. Plate 4: Fig. 6) differs from those in all species of the C. senegalense group (more blunt apex, Plate 3: Fig. 3. Plate 4: Figs 1-5). The apex in Jeannel's holotype of $C$. aethiops corresponds to that in the $C$. imbricatum group (Plate 3), which does not support the opinion of Bruschi (2013) that C. aethiops is a synonym of $C$. scabrosum roeschkei.

2. Shape of inflated endophalus. We have not found an apparent difference either among species or subspecies belonging to the same group, or among species belonging to different groups (Plate 4: Figs 1-5). This result does not support the opinion that shape of the endophalus can be used to indicate assignments to to species or species groups. 3. Morphometric parameters.

A. Total length including mandibles (TL). In three measured holotypes (or lectotypes) are the values within the minimum and maximum intervals found in corresponding populations and sexes, whereas in the male holotype of $C$. aethiops the value is outside of the interval. The TL value in the $C$. aethiops holotype is closest to the values found in males of $C$. $i$. hottentotum, and lies within the interval found in females of that subspecies (all types are males, see Table 1a, Table 2). This fact supports our opinion that the holotype of $C$. aethiops is an extremely large male of $C$. $i$. hottentotum.

B. Maximum pronotal width to maximum head width including eyes ratio (WP/ WH). The WP/WH in two measured holotypes (or lectotypes) is within the minimum and maximum intervals found in the pertinent populations and sexes. In the third taxon the WP/WH value of the holotype is outside of the interval in both sexes. In the holotype of $C$. aethiops is the WP/WH value within the interval found in the corresponding sex (males) of C. s. roeschkei and also within the interval found in C. $i$. hottentotum females. Overall the WP/WH values found in the measured taxa is very variable in both species and sexes (Table $1 \mathrm{~b}$, Table 2), and in our opinion thus cannot be used as a criterion in species-level taxonomy.

C. Maximum pronotal width to its maximum length ratio (WP/LP). The WP/ LP value in two measured holotypes (or lectotypes) is with exception of males of $C$. s. scabrosum within the minimum and maximum intervals found in the pertinent populations and sexes. In the holotype of $C$. aethiops is the WP/WH value within the interval found in all compared species of both sexes. Overall the WP/LP values found in the measured taxa are quite non-specific in both species and sexes (Table 1c, Table 2), and in our opinion thus cannot be used as a criterion in species-level taxonomy.

D. Maximum elytral length to its maximum width ratio (LE/WE). The WP/LP value in two measured holotypes (or lectotypes) is in both subspecies of $C$. scabrosum within the minimum and maximum intervals found in the pertinent populations and sexes. In both sexes of $C$. $i$. hottentotum the value is outside the interval. In the holotype of $C$. aethiops the value is within the interval found in both subspecies of $C$. scabrosum. Overall the WP/LP values found in the measured taxa can be regarded as variable, namely in $C$. $i$. hottentotum. In our opinion they cannot be used as a criterion in species-level taxonomy (Table 1d, Table 2). 
Table Ia. Total length, intervals.

\begin{tabular}{|c|c|}
\hline $\begin{array}{l}\text { Taxon } \\
\text { Holotype (HT), lectotype (LT) }\end{array}$ & $\begin{array}{l}\text { Total length including mandibles in millimeters (TL). Interval of } \\
\text { minimum and maximum value of TL measured in } 10 \text { specimens of the } \\
\text { same sex is in parentheses. } \\
\text { Yes }(Y) \text { - TL value of type is within interval. } \\
\text { No (N) - TL value of type is outside of interval. }\end{array}$ \\
\hline $\begin{array}{l}\text { C. scabrosum scabrosum Chaudoir, } 1843 \\
(\mathrm{HT} \precsim \overrightarrow{0})\end{array}$ & $25.5(23.1-26.2$ ふぇ゙) \\
\hline $\begin{array}{l}\text { C. scabrosum roeschkei Breuning, } 1927 \\
\left(\mathrm{HT}{ }^{\lambda}\right)\end{array}$ & $25.0(22.0-28.5 \precsim \precsim)$ \\
\hline $\begin{array}{l}\text { C. imbricatum hottentotum Chaudoir, } \\
1852 \text { (ฏै LT Deuve 1978) }\end{array}$ & $21.0(17.5-21.3 \precsim \precsim)$ \\
\hline C. aethiops (Jeannel, 1940) (HT ふै) & 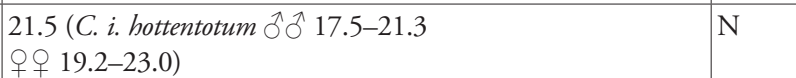 \\
\hline
\end{tabular}

Table I b. Pronotal width to head width ratio, intervals.

\begin{tabular}{|c|c|c|}
\hline $\begin{array}{l}\text { Taxon } \\
\text { Holotype (HT), lectotype (LT) }\end{array}$ & \multicolumn{2}{|c|}{$\begin{array}{l}\text { Maximum pronotal width to maximum head width inc. eyes } \\
\text { ratio }(\mathrm{WP} / \mathrm{WH}) \text {. Interval of minimum and maximum value } \\
\text { of WP/WH measured in } 10 \text { specimens of the same sex is in } \\
\text { parentheses. } \\
(\mathrm{Y} / \mathrm{Y}) \text { - value of type is within interval. } \\
(\mathrm{N} / \mathrm{N}) \text { - value of type is outside of interval. } \\
(\mathrm{N} / \mathrm{Y}) \text { - value of type is outside of interval in males but within } \\
\text { interval in females. }\end{array}$} \\
\hline C. scabrosum scabrosum Chaudoir, 1843 (HT ठ̂) & 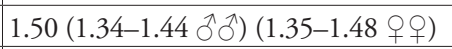 & $\mathrm{N} / \mathrm{N}$ \\
\hline C. scabrosum roeschkei Breuning, 1927 (HT ठ̂) & 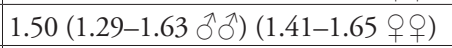 & $\mathrm{Y} / \mathrm{Y}$ \\
\hline $\begin{array}{l}\text { C. imbricatum hottentotum Chaudoir, } 1852 \text { (o } \\
\text { LT Deuve 1978) }\end{array}$ & $1.45(1.33-1.50$ ふึふึ) (1.23-1.54 우우) & $\mathrm{Y} / \mathrm{Y}$ \\
\hline C. aethiops (Jeannel, 1940) (HT ふै) & $\begin{array}{l}1.32 \text { (C. i. hottentotum) } \\
\text { (C. s. scabrosum) } \\
\text { (C. s. roeschkei) }\end{array}$ & $\begin{array}{l}\mathrm{N} / \mathrm{Y} \\
\mathrm{N} / \mathrm{N} \\
\mathrm{Y} / \mathrm{N}\end{array}$ \\
\hline
\end{tabular}

Table Ic. Pronotal width to length ratio, intervals.

\begin{tabular}{|c|c|c|}
\hline $\begin{array}{l}\text { Taxon } \\
\text { Holotype (HT), lectotype (LT) }\end{array}$ & \multicolumn{2}{|c|}{$\begin{array}{l}\text { Maximum pronotal width to maximum pronotal length ratio } \\
(\mathrm{WP} / \mathrm{LP}) \text {. Interval of minimum and maximum value of WP/LP } \\
\text { measured in } 10 \text { specimens of the same sex is in parentheses. } \\
(\mathrm{Y} / \mathrm{Y}) \text { - value of type is within interval. } \\
(\mathrm{N} / \mathrm{N}) \text { - value of type is outside of interval. } \\
(\mathrm{N} / \mathrm{Y}) \text { - value of type is outside of interval in males but within } \\
\text { interval in females. }\end{array}$} \\
\hline C. scabrosum scabrosum Chaudoir, 1843 (HT Љ) & 1.65 (1.33-1.56 ठึ & $\mathrm{N} / \mathrm{Y}$ \\
\hline C. scabrosum roeschkei Breuning, 1927 (HT Љ゙) & 1.67 (1.38-1.77 ふ઼ & $\mathrm{Y} / \mathrm{Y}$ \\
\hline $\begin{array}{l}\text { C. imbricatum hottentotum Chaudoir, } 1852 \text { (ð } \\
\text { LT Deuve 1978) }\end{array}$ & $1.74(1.43-1.74$ ठิ & $\mathrm{Y} / \mathrm{Y}$ \\
\hline C. aethiops (Jeannel, 1940) (HT ठ̂) & $\begin{array}{l}1.55 \text { (C. i. hottentotum) } \\
\text { (C. s. scabrosum) } \\
\text { (C. s. roeschkei) }\end{array}$ & $\begin{array}{l}\mathrm{Y} / \mathrm{Y} \mathrm{Y} / \mathrm{Y} \\
\mathrm{Y} / \mathrm{Y}\end{array}$ \\
\hline
\end{tabular}


Table Id. Elytral length to width ratio, intervals.

\begin{tabular}{|c|c|c|}
\hline $\begin{array}{l}\text { Taxon } \\
\text { Holotype (HT), lectotype (LT) }\end{array}$ & \multicolumn{2}{|c|}{$\begin{array}{l}\text { Maximum elytral length to maximum elytral width ratio } \\
\text { (LE/WE). Interval of minimum and maximum value of LE/ } \\
\text { WE measured in } 10 \text { specimens of the same sex is in parentheses. } \\
(\mathrm{Y} / \mathrm{Y}) \text { - value of type is within interval. } \\
(\mathrm{N} / \mathrm{N}) \text { - value of type is outside of interval. } \\
(\mathrm{N} / \mathrm{Y}) \text { - value of type is outside of interval in males but within } \\
\text { interval in females. }\end{array}$} \\
\hline C. scabrosum scabrosum Chaudoir, 1843 (HT ठ) & $1.44(1.44-1.56$ ふึ శో) $(1.38-1.53$ 우 $)$ & $\mathrm{Y} / \mathrm{Y}$ \\
\hline C. scabrosum roeschkei Breuning, 1927 (HT ठ̊) & 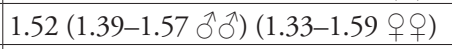 & $\mathrm{Y} / \mathrm{Y}$ \\
\hline $\begin{array}{l}\text { C. imbricatum hottentotum Chaudoir, } 1852 \\
\text { ( } \hat{A} \text { LT Deuve 1978) }\end{array}$ & 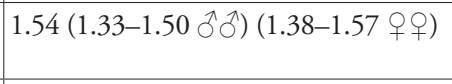 & $\mathrm{N} / \mathrm{Y}$ \\
\hline C. aethiops (Jeannel, 1940) (HT ふ) & $\begin{array}{l}1.39 \text { (C. i. hottentotum) } \\
\text { (C. s. scabrosum) } \\
\text { (C. s. roeschkei) }\end{array}$ & $\begin{array}{l}\mathrm{Y} / \mathrm{Y} \\
\mathrm{N} / \mathrm{Y} \\
\mathrm{Y} / \mathrm{Y}\end{array}$ \\
\hline
\end{tabular}

Table 2. Intervals of all measurements in each taxon (intervals), in TL and LE/WE for both sexes separately and total.

\begin{tabular}{c|c|c|c|c|c|c|c|c}
\hline C. s. scabrosum & $23.1-26.2$ & $23.1-26.2$ & $23.4-25.7$ & $1.35-1.63$ & $1.33-1.67$ & $1.38-1.56$ & $1.44-1.56$ & $1.38-1.53$ \\
\hline C. s. roeschkei & $22.0-28.5$ & $22.0-28.5$ & $24.1-27.9$ & $1.29-1.65$ & $1.38-1.77$ & $1.33-1.59$ & $1.39-1.57$ & $1.33-1.59$ \\
\hline C. senegalense & $23.0-30.0$ & $23.0-29.3$ & $24.9-30.0$ & $1.22-1.62$ & $1.30-1.73$ & $1.45-1.56$ & $1.45-1.55$ & $1.45-1.56$ \\
\hline C. strandi & $25.2-30.3$ & $25.2-29.0$ & $26.4-30.3$ & $1.32-1.44$ & $1.46-1.62$ & $1.44-1.64$ & $1.50-1.64$ & $1.44-1.64$ \\
\hline $\begin{array}{c}\text { C. } i . \\
\text { imbricatum }\end{array}$ & $17.0-22.0$ & $17.0-20.4$ & $18.2-22.0$ & $1.33-1.43$ & $1.41-1.68$ & $1.26-1.57$ & $1.39-1.53$ & $1.26-1.57$ \\
\hline $\begin{array}{c}\text { C. } i . \\
\text { bottentotum }\end{array}$ & $17.5-23.0$ & $17.5-21.3$ & $19.2-23.0$ & $1.33-1.54$ & $1.43-1.84$ & $1.33-1.57$ & $1.33-1.50$ & $1.38-1.57$ \\
\hline
\end{tabular}

The above data lead us to conclude that there are no convincing morphological differences between $C$. scabrosum scabrosum and $C$. scabrosum roeschkei. The only exception may possibly be the somewhat higher WP/LP ratio (Table 2) and lighter coppery coloration in most specimens of C. s. roeschkei. Since specimens of both taxa have never been found together, we assume that they belong to allopatric populations of one species that have yet to reach the state of full speciation. Therefore, we lower the status of C. roeschkei (sensu Bruchi 2013) to a subspecies of C. scabrosum. Calosoma scabrosum roeschkei occupies mainly the southern part of distribution of the species. The present data show the north - south distribution of both subspecies to have a virtually disjunct character (Map 1). But it is in our opinion important to realize that in no area have the described subspecies been found to occur together. It is therefore likely that the northern Sudan - Ethiopia borderland will continue to produce C. s. roeschkei. The describer (Breuning 1927: 186) of Calosoma scabrosum roeschkei wrote: ["This form (roeschkei) is due to its more robust head, less bulging eyes, wider, toward base more right-angled pronotum with more rounded hind angles, shallower basal pits, somewhat flatter, at shoulders broader and terminally more abruptly slanted elytra and dark to brownish bronze dorsal coloration with light brown, coppery-rimmed margins and foveae in primary intervals so 


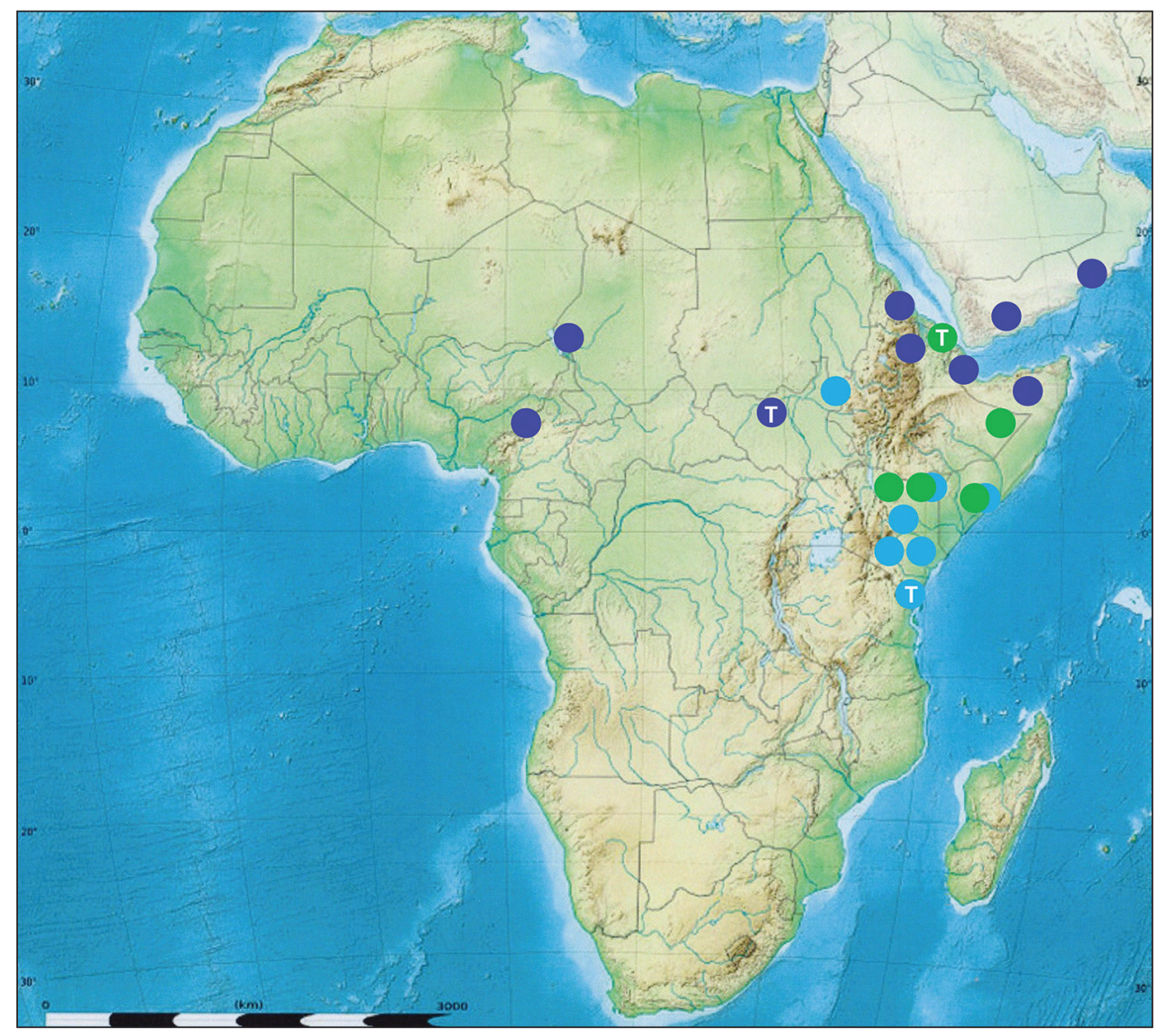

Map I. Geographic distribution of the Calosoma scabrosum and Calosoma strandi species subgroups (sensu Häckel 2012). T - the type locality. Dark blue discs - Calosoma scabrosum s. str. Chaudoir, 1843. Light blue discs - Calosoma scabrosum roeschkei Breuning, 1927. Green discs - Calosoma strandi Breuning, 1934.

conspicuous that I originally intended to describe it as a separate species. However, some individuals of this form (roeschkei) are clearly transitional to the typical form (scabrosum), with coloration remaining as the only constant character. Differences (of separate populations) from the nominotypical form show step-like transitions, for which reason I presently regard C. roeschkei as a subspecies of C. scabrosum" (original in German)].

Jeannel (1940: 128) did not see Breuning's subspecies but treated it as a variety and remarked: ["Breuning's variety roeschkei rather appears to be another (separate) species closely related to C. scabrosum]"; he did not further comment on the taxon and placed specimens corresponding to Breuning's description among African populations of "C. orientale" (Jeannel 1940: 128). In this connection, Jeannel and subsequent authors such as Rougemont (1976: 247) and Vigna Taglianti and Bruschi (1986: 21) solved taxonomic uncertainties by incorrect determination of specimens from eastern 
Africa as C. squamigerum Chaudoir, 1869 (Häckel 2012: 57.). The holotype of $C$. squamigerum is from Bengal (today either Bangladesh or West Bengal in India) and other specimens of the type series are from Coimbatore in the vicinity of Madras (today Tamilnadu State in southern India). The name C. squamigerum was therefore synonymized with C. orientale (Jeannel 1940: 128).

Jeannel nevertheless realized that African populations identified as C. orientale (=squamigerum) most likely belong to another species, coined for them a new taxon, Ctenosta (s. str.) aethiops Jeannel, 1940, and included in the distribution of this taxon also populations corresponding to Breuning's C. s. roeschkei ("Diré Daoua", Jeannel 1940: 128). The only exception was a population from Eritrea ("Tessenei" 1940:129), which he continued regarding as $C$. orientale. In the description of $C$. aethiops Jeannel (1940: 127-128) wrote: ["if we regard C. aethiops with its gular and labial setae as belonging to the genus Caminara, we can see that in reality it is a transitional species combining characters of Caminara and Ctenosta, an important species attesting to its assignment to the genus Ctenosta, which differs by reduction of the said setae and the type of sculpture placing it near the Castrida-Caminara lineage. The male mesotibiae have the setal brush prolonged as in Caminara and similar to that present in Ctenosta. The ventral side of the fourth male protarsomere is smooth]".

Evident from Jeannel's text are the difficulties he had in placing the new species in his system and in defining the "genera". More recently some authors (Culot 1990, Bousquet et al. 2003, Bruschi 2013) regarded the genera as subgenera, but in our opinion Jeannel's criteria do not allow to distinguish them. For instance Bruschi in the key does not adhere to Jeannel's criteria (setae, elytral microsculpture) and originally separates Caminara from Ctenosta on the hind pronotal angles. In the key he (2013: 29) states: "13(14) always perceptible hind angles of pronotum - Caminaral Campalita; 14(13) very small and pointed hind angles of pronotum, in some cases quite obliterated". In our opinion Jeannel's genera are not valid, which is supported also by their discord with results of DNA analyses. With only one exception, all the subgenera were synonymized with the genus Calosoma s. str. (Häckel 2012: 56, 2013: 12). Jeannel's difficulties in separating the "genera" Ctenosta and Caminara (according to us two close species groups of the genus Calosoma) reflect the confused composition of the type series of his $C$. aethiops. Without examination of Jeannel's holotype of $C$. aethiops, most subsequent authors regarded all African populations similar to C. scabrosum, with golden bronze coloration, as C. (Ctenosta) aethiops (Vigna Taglianti and Bruschi 1986: 21, Culot 1990: 9, Lorenz 2005: 68).

Only Bruschi, first on the internet and later in print (2013: Plate 17: Figs 8, 9), published photos of the holotypes of $C$. scabrosum roeschkei (Tanzania: Usambara) and C. aethiops (Niger: Azbin). The holotype of C. s. roeschkei (Usambara, see Map 1) clearly is a species belonging to the $C$. senegalense group, and we concur with Bruschi that in compliance with the priority principle the taxon must be ascribed to Breuning (the name C. s. roeschkei has priority over C. aethiops, if the two are the same species).

However, in our opinion the specimen from Azbin (Jeannel's holotype of C. aethiops) looks different and does not belong to the $C$. senegalense group (=Jeannel's genus 
Ctenosta). Our comparisons of types and their aedeagi show that the holotype of $C$. aethiops corresponds in shape, size and sculpture of the elytra, shape of the legs, and termination of the aedeagus to $C$. imbricatum hottentotum Chaudoir, 1852. It belongs to another group (C. maderae group, C. imbricatum subgroup sensu Häckel, 2013: =Jeannel's genus Caminara), which partially overlaps the distribution of the C. senegalense group. Our conclusions are based chiefly on the different aedeagal morphology unequivocally shown by the photos (Plate 3, Figs 1, 2 versus Fig. 3). Futher documentation of morphological characters is not needed.

Calosoma imbricatum sensu lato is by a number of authors understood as a species with an extremely wide distribution reaching from Canary and Cape Verde Islands through the African Sahel belt, subsaharan Africa, Arabia, Iran and Pakistan to India and Bagladesh (Breuning 1927: 221-223, Jeannel 1940: 104-106, Mandl 1970: 61-63, see Map 2). The cited authors identify southern African populations of $C$. imbricatum as the subspecies $C$. $i$. hottentotum, whose holotype comes from the Cape province (Chaudoir 1852: 99). Calosoma imbricatum hottentotum is usually regarded as cofined to southern Africa, and Mandl (1970: 61, 63) even named another subspecies, C. i. linnavourii, for populations from eastern Africa (northern Kenya, Somalia), which is a transitional form differing from the northern (Sahel-Arabian) nominotypical form (C. i. imbricatum) by wider pronotum. Populations from southern Kenya and northern Tanzania with more lighter coppery coloration approaching rather the southern African populations (C. $i$. hottentotum). Jeannel (1940: 105) is the only author who regarded also the Kenya population as $C$. i. hottentotum. Mandl (1970: 63) commented these occurrences as "Wahrnscheinlich gehören die folgende Orte zu dieser Subspecies [C. i. linnavourii]: Kenya Sultan Hamid zwischen Voi und Nairobi, die Jeannel für hottentottum angibt", and Bruschi (2013) countered: „It seems that, contrary to the opinions of Mandl (1970: 61) that attributed this citation to his $C$ imbricatum linnavourii, Jeannel is right since in south western Kenya $C$ imbricatum hottentotum is really present". In our opinion it is evident that the northern limit of $C$. $i$. hottentotum is vague and hosts a number of forms transitional to the nominotypical $C$. i. imbricatum. It is therefore possible that Jeannel's type of $C$. aethiops from Azbin (today northern Niger) belongs to one of the transitional populations and the locality is in fact correct (see Map 2). In our opinion Jeannel's type series of $C$. aethiops contains the holotype that we regard as Calosoma imbricatum (most likely the subspecies hottentotum) and specimens from other populations belonging to some of the subspecies of $C$. scabrosum, mostly to C. s. roeschkei.

Comparison of the types of C. s. scabrosum and C. s. roeschkei in our opinion also confirms the original Breuning's idea of one species with two terminal forms and a number of transitional forms between them (Plate 1: Figs 1-2). Another taxonomical inaccuracy was caused by Häckel et al. (2005: 2), who believed that populations newly discovered on the Arabian peninsula (Oman, Yemen, see Map 1) represent a different species (C. jakli, Plate 2. Fig. 2). Eventually, after comparison with the type of $C$. $s$. scabrosum it became clear that the Arabian specimens agree with the type (Häckel et al. 2010: 11), and today they are included in the distribution of the nominotypical subspecies C. scabrosum s. str. (Müller 1977, Häckel 2012: 57). 


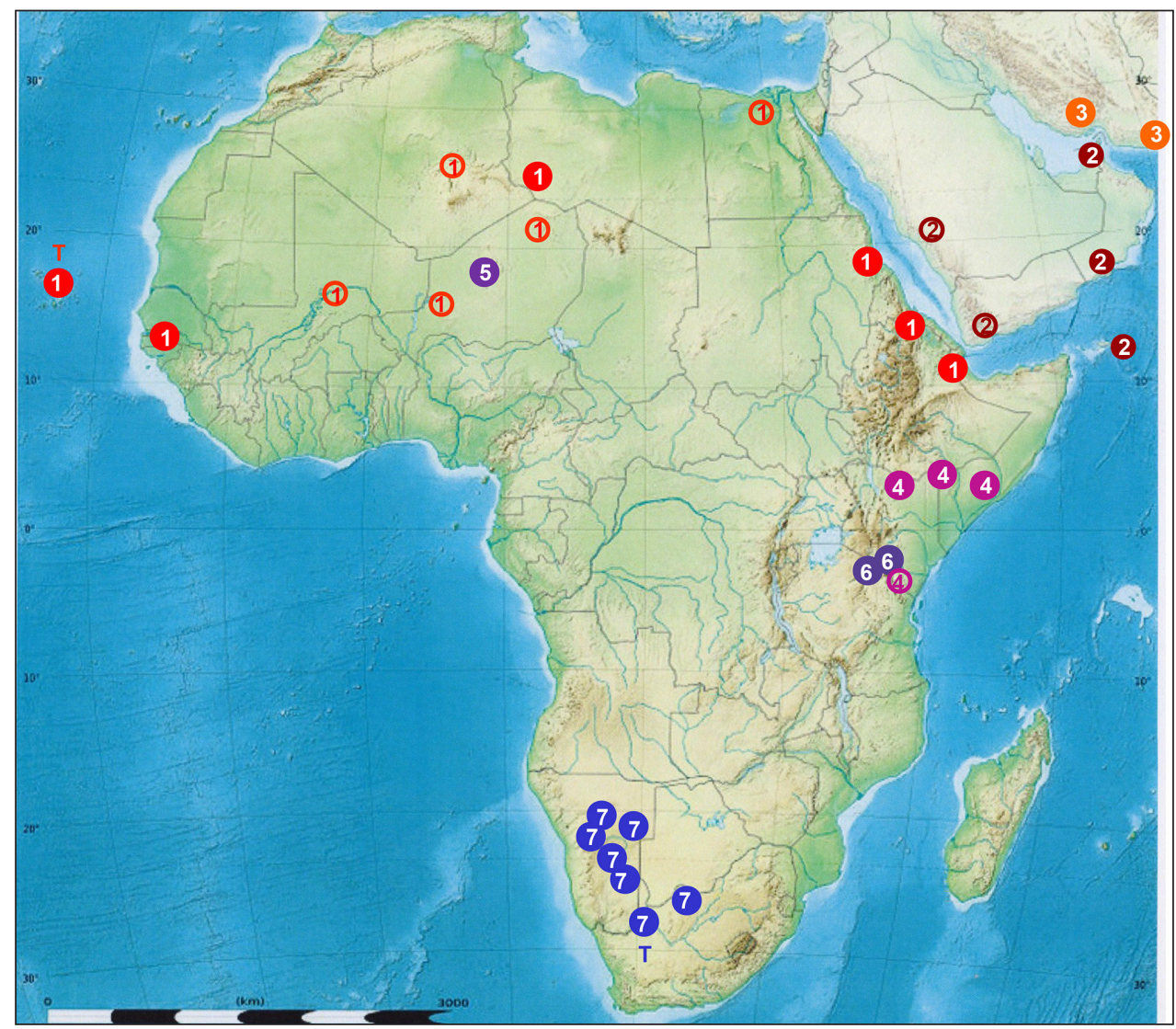

Map 2. Geographic distribution of the Calosoma imbricatum species subgroup (sensu Häckel 2013) compared to Mandl's data (1970) and C. imbricatum hottentotum Chaudoir, 1852. T - the type locality, - (full disc) - recent records, O (empty disc) - Mandl's data I-4 Calosoma imbricatum s. str. Klug, 1832 5-7 Calosoma imbricatum hottentotum Chaudoir, 1852 I C. imbricatum s. str. (sensu Mandl 1970) 2 C. imbricatum arabicum (Motschulsky, 1865) sensu Mandl 19703 C. imbricatum löfleri Mandl, 1953 sensu Mandl 19704 C. imbricatum linnavourii Mandl, 1970 sensu Mandl 19705 C. imbricatum hottentotum (holotype of Ctenosta aethiops Jeannel, 1940) 6 C. imbricatum hottentotum (C. imbricatum linnavourii sensu Mandl 1970) 7 C. imbricatum hottentotum. sensu Mandl 1970.

Below we present morphometric tables comparing populations of C. s. roeschkei (hitherto labeled as C. aethiops) with specimens of C. s. scabrosum the Horn of Africa (Djibouti) and the Arabian peninsula (Oman, Yemen). The tables also compare the noted populations of $C$. scabrosum with specimens of $C$. i. hottentotum from southern and eastern Africa and C. i. imbricatum from Afrotropical Region. In this connection we consider it important that no known locality has produced sympatrically living C. s. scabrosum and C. s. roeschkei (see Map 1). However, at at least one locality (Kenya: North-Eastern Province, El Wak, see Map 1) has produced C. scabrosum (ssp. roeschkei) together with C. imbricatum (ssp. hottentotum) and another species of the C. senegalense group (C. strandi Breuning). 
Our conclusion therefore is that Breuning's (1928: 185) original idea is valid, and consequently we demote $C$. roeschkei sensu Bruschi (2013: 129) to a subspecies of $C$. scabrosum.

The subgeneric placement of $C$. imbricatum, $C$. in the subgenus Calosoma follows the recently proposed classification supported by results of DNA analyses ( $\mathrm{Su}$ et al. 2005, Häckel 2012, 2013).

\section{Acknowledgements}

We thank Tomás Sýkora (Kladno) for help in preparation of the endophalli and photos, Boleslav Březina (Praha) for photography, and Jiř́ Zídek (Praha) for translating the text.

\section{References}

Bousquet Y, Březina B, Davies A, Farkač J, Smetana A (2003) Carabini. In: Löbl I, Smetana A (Eds) The Catalogue of Palaearctic Coleoptera. Vol. 1. Apollo Books, Stenstrup, $118-201$.

Breuning S (1927) Monografie der Gattung Calosoma Web. (Carab.). Koleopterologische Rundschau 13: 129-232.

Breuning S (1934) Ueber Carabini. Folia Zoologica et Hydrobiologica 31(8): 29-40.

Bruschi S (2013) Calosoma of the World (Coleoptera, Carabidae). Bologna, Natura Edizioni Scientifiche di Alfonso Iorio, 314 pp. +39 pl.

Chaudoir M de (1843) Carabiques nouveaux. Bulletin de la Société Impériale des Naturalistes de Moscou 16: 671-791.

Chaudoir M de (1852) Mémoire sur la famille des carabiques. 3e partie. Bulletin de la Société Impériale des Naturalistes de Moscou 25(1): 1-104.

Chaudoir M de (1869) Descriptions de Calosoma nouveaux des collections de M. M. de Chaudoir et Salle. Annales de la Société Entomologique de France 9 (4. série): 367-378.

Culot J (1990) Catalogue des Calosomes du monde. Bruxelles, privately published, 19 pp.

Dejean PFMA (1831) Species général des coléoptères, de la collection de M. le Comte Dejean. Tome cinquième. Paris, Méquignon-Marvis, viii + 883 pp.

Deuve T (1978) Liste des types de calosomes du Muséum National d'Histoire Naturelle de Paris. Nouvelle Révue d'Entomologie 8(3): 245-258.

Farkač J, Häckel M (2012) Calosoma chlorostictum ivinskisi, a new synonym of Calosoma chlorostictum chlorostictum (Coleoptera: Carabidae: Carabini). Acta Entomologica Musei Nationalis Pragae 52 (suppl. 2): 69-73.

Häckel M (2012) Three new records of caterpillar hunters of the genus Calosoma Weber 1801 (Coleoptera: Carabidae: Carabini) from Afrotropical and Palearctic regions. Folia Heyrovskyana, series A, vol. 20(1-2): 55-65.

Häckel M (2013) Kritický náhled na současnou infragenerickou systematiku rodu krajník Calosoma, Carabini, Carabidae) [A critical overview on the recent infrageneric taxonomy of 
the caterpillar hunter (Calosoma, Carabini, Carabidae)]. Diploma's Work. Czech University of Life Sciences Prague, Faculty of Environmental Sciences, Department of Ecology. Prague, 86 pp. + 2 appendices. [In Czech with English abstracts]

Häckel M, Farkač J, Sehnal R (2005) A new species of Calosoma (Coleoptera: Carabidae: Carabini) from Oman and a new subspecies of Calosoma oceanicum Perroud \& Montrouzier 1864 from the Lombok Island (Lesser Sunda, Indonesia). Animma-X 11: 1-7.

Häckel M, Farkač J, Sehnal R (2010) New status of Calosoma jakli Häckel, Farkač \& Sehnal, 2005 (Coleoptera: Carabidae: Carabini). Animma-X 31: 11-13.

Harold E Von (1880) Beschreibungen neuer, auf seiner, von der Akademie unterstützten Reise in Ostafrika, vorzüglich in den Districten von Taita und Ukamba auf einer Tour von Mombassa nach dem Kenia, von Hrn. M. J. Hildebrandt gesammelter Coleopteren. Monatsberichte der Königlich preussischen Akademie der Wissenschaften zu Berlin, 260.

Jeannel R (1940) Les calosomes (Coleoptera, Carabidae). Mémoires du Muséum National d'Histoire Naturelle (Paris) 13: 1-240.

Klug JCF (1853) Ubersicht der von Hrn dr Peters wahrend seines Aufenhalts in Mozambik veranstalteten entomologischen Sammlungen. Monatsberichte der Berliner Akademie der Wissenschaften 1853: 244-250.

Lapouge G Vacher De (1931) Coleoptera Adephaga, Fam. Carabidae. Subfam. Carabinae, pt. 3. In: Wytsman P (Ed.) Genera Insectorum, fasc. 192B. Desmet-Verteneuil, Bruxelles, 293-580.

Lorenz W (2005) Systematic List of extant Ground Beetles of the World (Insecta Coleoptera "Geadephaga“: Trachypachidae and Carabidae incl. Paussinae, Cicindelinae, Rhysodinae). Second Edition. Wolfgang Lorenz, Tutzing, 530 pp.

Mandl K (1970) Calosoma chlorostictum Dejean und Calosoma imbricatum Klug. Koleopterologische Rundschau 48: 57-63.

Motschulsky V de (1865) Enumeration des nouvelles espèces de coléoptères rapportés de ses voyages. 4-ème article (suite). Bulletin de la Société Impériale des Naturalistes de Moscou 38(4): 227-313.

Müller P (1977) Tiergeographie. Struktur, Funktion, Geschichte und Indikatorbedeutung von Arealen. Stuttgart, Teubner, 268 pp.

Rougemont GM de (1976) Contributions à la connaissance de la faune de l'Ethiopie. I. Les Calosomes (Coleoptera: Carabidae). Revue de Zoologie africaine 90(2): 241-274.

Su Z-H, Imura Y, Osawa S (2005) Evolutionary history of Calosomina ground beetles (Coleoptera, Carabidae, Carabinae) of the world as deduced from sequence comparisons of the mitochondrial ND5 gene. Gene 360: 140-150. doi: 10.1016/j.gene.2005.06.028

Vigna Taglianti A, Bruschi S (1986) Note sui Calosomini dell'Ethiopia. Memoire della Societa Entomologica Italiana 65: 3-28. 